\title{
REAKSI PASAR DI SEPUTAR PENGUMUMAN PROPER \\ (PROGRAM PENILAIAN PERINGKAT KINERJA PERUSAHAAN DALAM PENGELOLAAN LINGKUNGAN HIDUP)
}

\author{
Verena Winardi Kusumo dan Yeterina Widi Nugrahanti \\ Fakultas Ekonomika dan Bisnis Universitas Kristen Satya Wacana \\ email: yeterina.nugrahanti@staff.uksw.edu
}

\begin{abstract}
The purpose of this research is to examine the change of market reaction around the date of Corporate Performanice Rating program in Environ mental management (PROPER) announcement and the change of market reaction between good PROPER rank and bad PROPER rank. The market reaction is measured by abnormal return and trading volume activity. The sample of the study consist of 25 companies which joined on PROPER and listed on the Indonesian Stock Exchange in 2009-2013. Data that used in this study consist of share's daily closing price and daily trading volume. The research period is 7 days by using market-adjusted model. Analyzed technique for examining the hypothesis is Wilcoxon Signed Test at level significant of 5\%. The result of this research shows that PROPER announcement get any response from the investor, because there were significant changes to the abnormal return. But there were no significant changes to the trading volume activity before and after PROPER announcement, abnormal return and trading volume activity between good PROPER rank and bad PROPER rank.
\end{abstract}

Keywords: PROPER, abnormal return, trading volume activity

\begin{abstract}
Abstrak: Tujuan dari penelitian ini adalah untuk menguji perubahan reaksi pasar sekitar pengumuman pengumuman PROPER dan perubahan reaksi pasar antara peringkat PROPER yang baik dan peringkat PROPER yang buruk. Reaksi pasar diukur dengan abnormal return dan aktivitas volume perdagangan. Sampel penelitian terdiri dari 25 perusahaan yang tergabung dalam PROPER dan terdaftar di Bursa Efek Indonesia pada tahun 2009-2013. Data yang digunakan dalam penelitian ini terdiri dari harga penutupan harian saham dan volume perdagangan harian. Periode penelitian adalah 7 hari dengan menggunakan model yang disesuaikan dengan pasar. Teknik yang dianalisis untuk menguji hipotesis adalah Wilcoxon Signed Test pada tingkat signifikansi 5\%. Hasil penelitian menunjukkan bahwa PROPER pengumuman mendapat respon dari investor, karena ada perubahan signifikan terhadap abnormal return. Namun tidak ada perubahan yang signifikan terhadap aktivitas volume perdagangan sebelum dan sesudah pengumuman PROPER, abnormal return dan volume aktivitas perdagangan antara peringkat PROPER yang baik dan peringkat PROPER yang buruk.
\end{abstract}

Kata kunci: PROPER, return abnormal, aktivitas volume perdagangan

\section{PENDAHULUAN}

Tindakan eksploitasi lingkungan yang berujung pada pencemaran menjadi permasalahan untuk tingkat regional, nasional, maupun internasional. Adapun kasus pencemaran yang telah terjadi di Indonesia seperti yang dilansir oleh Berita Jateng yaitu pencemaran air oleh PT Sidomuncul, di mana perusahaan membuang limbah cair ke 
Sungai Klampok, Kabupaten Semarang. Tempo Co merilis berita lain yaitu kasus PT Newmont Minahasa Raya yang merusak ekosistem perairan laut di Teluk Buyat. Perusahaan akhirnya menandatangani goodwill agreement dan membayar ganti rugi sebesar US \$ 30 juta agar gugatan perdata atas kasus tersebut dibatalkan. Pembayaran sanksi kepada pemerintah merupakan suatu biaya yang berujung kepada kerugian keuangan bagi perusahaan.

Pencemaran juga menyebabkan kerusakan lingkungan hidup sehingga citra perusahaan dikhawatirkan akan menjadi buruk di mata masyarakat dan keberlangsungan usahanya untuk masa mendatang akan terancam. Oleh sebab itu perusahaan kini tidak hanya berfokus terhadap perolehan laba saja, tetapi juga berfokus pada kesejahteraan masyarakat dan lingkungan. Tindakan perusahaan dalam melaksanakan ketiga aspek 3P (Profit, People, dan Planet) disebut dengan Corporate Social Responsibility (CSR). Berdasarkan UU No. 40 Tahun 2007, CSR adalah komitmen Perseroan untuk berperan serta dalam pembangunan ekonomi berkelanjutan guna meningkatkan kualitas kehidupan dan lingkungan yang bermanfaat, baik bagi Perseroan sendiri, komunitas setempat, maupun masyarakat pada umumnya. Bentuk program CSR dapat berupa promosi kegiatan sosial, pengembangan masyarakatan,

Tanggung jawab terhadap lingkungan tidak hanya diperhatikan oleh perusahaan, tetapi juga gencar dilakukan oleh pemerintah, di mana pemerintah berkontribusi dalam mengadakan Program Penilaian Peringkat Kinerja Perusahaan dalam Pengelolaan Lingkungan Hidup (PROPER). Peserta PROPER adalah perusahaan-perusahaan yang menimbulkan dampak penting terhadap lingkungan, tercatat di pasar bursa, dan mempunyai produk yang berorientasi ekspor atau digunakan oleh masyarakat luas.

Peringkat yang diperoleh oleh perusahaan akan diwakili dengan warna yang telah ditetapkan Kementerian Lingkungan Hidup. Menteri Lingkungan Hidup menetapkan bahwa nilai tertinggi adalah warna emas, kemudian disusul dengan warna hijau, biru, merah, dan untuk nilai terendah yaitu warna hitam. Perusahaan yang memperoleh peringkat hitam, akan diberi sanksi hukum sesuai peraturan (Prabandari dan Suryanawa, 2014).

Environmental performance yang dicerminkan melalui peringkat PROPER merupakan usaha manajemen perusahaan untuk mewujudkan lingkungan yang selaras, serasi, seimbang di mana akan membangun citra yang baik di mata stakeholders (Ikhsan, 2009). Perusahaan yang memiliki kinerja lingkungan yang baik akan cenderung melakukan pengungkapan kepada pihak luar. Kinerja yang baik akan membuat investor tertarik untuk menanamkan modalnya. Oleh karena itu, penanaman modal tersebut akan memberikan kenaikan return saham dan pertambahan volume perdagangan saham.

Beberapa penelitian terdahulu mengenai kinerja lingkungan dan reaksi pasar pernah dilakukan. Wiranata dan Wirajaya (2012) telah menemukan bahwa pengumuman peringkat kinerja perusahaan dalam mengelola lingkungan dari PROPER memiliki kandungan informasi sehingga direaksi oleh pasar yang ditunjukkan dengan adanya abnormal return yang signifikan pada saat pengumuman dan dua hari setelah tanggal pengumuman. Namun Wiranata dan Wirajaya (2012) tidak menemukan perbedaan reaksi pasar antara peringkat emas dan peringkat merah. Udayanti (2012) menemukan bahwa selisih harga saham perusahaan PROPER dan perusahaan Non-PROPER tidak mengalami perbedaan yang signifikan.

Reddy dan Gordon (2010) menemukan bahwa CSR berpengaruh signifikan terhadap abnormal return bagi perusahaan-perusahaan di New Zealand. Penelitian ini 
menemukan ada perbedaan abnormal return pada hari pertama pelaporan kinerja lingkungan tahunan, tetapi pada hari-hari selanjutnya tidak terdapat perbedaan abnormal return dalam pelaporan kinerja lingkungan.

Linuwih dan Nugrahanti (2014) meneliti salah satu penghargaan yang berfokus terhadap kinerja perusahaan dalam melaporkan aspek ekonomi, sosial dan lingkungan bisnis yaitu Indonesia Sustainability Reporting Award (ISRA). Peneliti menemukan bahwa tidak ada perbedaan signifikan pada abnormal return. Penelitian ini juga menemukan terdapat perbedaan Trading Volume Activity (TVA) yang signifikan pada hari kelima dan kedua sebelum tanggal pengumuman dan sehari sesudah pengumuman ISRA.

Widarwati dan Lisviani (2015) meneliti perbedaan return saham pada perusahaan PROPER, Non PROPER dan ANTAR PROPER. Kesimpulan atas penelitian tersebut adalah perkembangan return saham perusahaan PROPER dan Non PROPER di setiap tahunnya mengalami fluktuasi, sedangkan perkembangan return saham perusahaan Antar PROPER pada peringkat emas, biru, dan hijau di setiap tahunnya mengalami peningkatan. Setelah dilakukan uji $\mathrm{T}$ ditemukan hasil bahwa ada perbedaan rata-rata return saham perusahaan PROPER dengan perusahaan Non PROPER. Uji ANOVA untuk perusahaan ANTAR PROPER dilakukan dengan membandingkan perusahaan-perusahaan tersebut dan hasilnya memperlihatkan bahwa ada beda return saham pada perusahaan ANTAR PROPER.

Penelitian ini menguji adakah perbedaan reaksi pasar sebelum dan sesudah pengumuman PROPER dan adakah perbedaan reaksi pasar antar peringkat PROPER. Penelitian dilakukan pada perusahaan PROPER tahun 2009-2013 dan penelitian penting untuk dilakukan karena hasil penelitian Widarwati dan Lisviani (2015) mengenai reaksi pasar terkait abnormal return menunjukkan bahwa hasil yang tidak konsisten dengan penelitian sebelumnya [Wiranata dan Wirajaya (2012), Udayanti (2012), serta Linuwih dan Nugrahanti (2014)]. Peneliti menambahkan variabel volume perdagangan saham dalam penelitian ini sehingga variabel reaksi pasar ada 2 yaitu variabel abnormal return dan volume perdagangan saham.

Return saham mencerminkan aliran kas periodik dari suatu investasi serta kenaikan atau penurunan harga saham. Kenaikan harga saham memberikan keuntungan bagi investor, sedangkan penurunan harga saham memberikan kerugian bagi investor. Return berkaitan dengan uncertainty sehingga muncul risiko investasi. Sedangkan volume perdagangan saham merupakan jumlah saham yang diperdagangkan dibandingkan dengan jumlah saham pada kurun waktu tertentu. Volume perdagangan saham merefleksikan perubahan dalam pengharapan investor individual (Bandi dan Hartono, 2000). Informasi yang timbul dari suatu pengumuman akan membawa perubahan kepercayaan yang akan memotivasi investor dalam melakukan kegiatan perdagangan.

Permintaan saham yang tinggi, tetapi tidak diikuti dengan penawaran yang tinggi akan menyebabkan harga saham naik, sehingga investor (seller) menjual saham demi capital gain, sedangkan buyer membeli saham demi mendapatkan abnormal return yang tinggi di masa mendatang. Hal ini menyebabkan saham lebih likuid dan diminati oleh investor. Menurut Hendrawaty (2010) jika saham likuid maka lebih mudah ditransaksikan sehingga terdapat peluang untuk mendapatkan capital gain.

Tujuan dari penelitian ini adalah untuk mengetahui adakah perbedaan reaksi pasar sebelum dan sesudah pengumuman PROPER dan pada antar peringkat PROPER. Manfaat penelitian ini adalah (1) memberikan informasi bagi perusahaan untuk menciptakan citra 
positif di masyarakat yang pada akhirnya diharapkan meningkatkan abnormal return dan volume perdagangan saham; (2) memberikan informasi dan pengetahuan bagi investor dalam melakukan pengambilan keputusan investasi terkait dengan pengumuman PROPER; (3) landasan untuk penelitian selanjutnya di bidang pasar modal.

\section{KAJIA TEORI}

Teori Sinyal (Signalling Theory). Sinyal adalah sebuah tindakan yang diambil oleh manajemen perusahaan yang memberikan petunjuk kepada investor tentang bagaimana manajemen memandang prospek perusahaan (Besley dan Brigham, 2008). Sinyal dapat berupa promosi, informasi mengenai apa yang sudah dilakukan oleh agent untuk merealisasikan tujuan principal, atau informasi lain yang menyatakan bahwa perusahaan tertentu lebih baik daripada pesaing. Informasi harus lengkap, relevan, akurat dan tepat waktu agar dapat dijadikan sebagai alat analisis dalam pengambilan keputusan investasi oleh stakeholder. Teori sinyal mempunyai pandangan bahwa profitable company memberi informasi yang lebih baik untuk pasar dan mendorong naiknya return dan bertambahnya volume perdagangan saham.

Menurut Hartono (2014), informasi yang dipublikasikan sebagai suatu pengumuman akan memberikan sinyal bagi investor dalam pengambilan keputusan investasi. Jika pengumuman tersebut mengandung nilai positif, maka diharapkan pasar akan bereaksi pada waktu pengumuman tersebut diterima oleh pasar.

Keputusan investasi umumnya menggunakan profitabilitas sebagai ukurannya karena profitabilitas akan menunjukkan kondisi kesehatan perusahaan (Adi, 2013). Akan tetapi perspektif itu mengalami pergeseran dari yang semula hanya mempertimbangkan aspek profitabilitas dan kemudian beralih dengan mempertimbangkan pula kinerja lingkungan perusahaan. Profitabilitas yang didukung dengan kinerja lingkungan yang baik dianggap akan memberikan kontribusi yang lebih baik dalam bentuk kenaikan return bagi stakeholder. Oleh karena itu, dalam teori sinyal dinyatakan bahwa informasi yang diungkapkan perusahaan kepada publik akan ditangkap oleh investor atau pasar sebagai sinyal-sinyal yang nantinya dijadikan dasar pertimbangan membuat suatu keputusan berinvestasi (Dewi, 2011).

Perolehan PROPER memberikan sinyal bagi investor karena PROPER mencerminkan kinerja lingkungan perusahaan dan gambaran mengenai prospek perusahaan di masa mendatang. Perusahaan yang memperoleh peringkat baik dianggap memiliki prospek yang baik dan diharapkan akan terbebas dari kasus pencemaran di masa mendatang. Good news ini merangsang investor untuk berinvestasi sehingga abnormal return akan naik dan memperdagangkan sahamnya sehingga volume perdagangan saham bertambah.

Studi Peristiwa (Event Study). Penelitian ini merupakan suatu studi peristiwa (event). Studi ini mempelajari reaksi pasar terhadap suatu peristiwa yang informasinya dipublikasikan sebagai suatu pengumuman yaitu pengumuman PROPER. Reaksi pasar diamati pada periode sebelum dan sesudah pengumuman PROPER.

Beberapa asumsi yang diterapkan oleh Mc Williams dan Siegel (1997) dalam Hartono (2010) ketika melakukan event study adalah: Pertama. Asumsi efisiensi pasar. Pasar efisien dapat terjadi karena peristiwa sebagai berikut: (a) Investor adalah price taker yang tidak dapat mempengaruhi pasar. Harga sekuritas ditentukan oleh permintaan dan penawaran pasar modal; (b) Informasi tersedia secara luas kepada semua pelaku pasar pada saat yang bersamaan dan harga untuk memperoleh informasi murah; (c) Investor tidak dapat memprediksikan kapan emiten akan mengumumkan informasi yang baru; (d) Investor menggunakan informasi secara penuh dan cepat sehingga harga dari sekuritas berubah dengan semestinya dan mencerminkan informasi untuk mencapai keseimbangan 
yang baru. Kedua. Asumsi peristiwa-peristiwa tidak diantisipasi. Peristiwa diasumsikan bahwa peristiwa belum dan tidak diantisipasi sebelumnya, sehingga reaksi pasar merupakan hasil dari peristiwa tersebut. Ketiga. Asumsi tidak ada efek penganggu (confounding effect). Reaksi pasar yang terjadi diakibatkan karena peristiwa yang diteliti, bukan akibat peristiwa lainnya sehingga peristiwa lainnya tidak boleh ada dan terjadi di sepanjang periode penelitian karena peristiwa tersebut akan memberikan efek penganggu.

\section{Program Penilaian Peringkat Kinerja Perusahaan dalam Pengelolaan Lingkungan}

Hidup (PROPER). PROPER merupakan program sukarela dari kementerian lingkungan hidup yang memberikan pemeringkatan terhadap perusahaan dalam mengelola lingkungannya (Wiranata dan Wirajaya 2012). Sekretariat Kementerian Lingkungan Hidup menetapkan bahwa pemberian penghargaan PROPER didasarkan pada penilaian kinerja penanggung jawab usaha dan/ atau kegiatan: (a) Pencegahan pencemaran dan/atau kerusakan lingkungan hidup, (b) Penanggulangan pencemaran dan/atau kerusakan lingkungan hidup, (c) Pemulihan pencemaran dan/atau kerusakan lingkungan hidup.

Adapun kriteria PROPER dalam menilai kinerja yang terdiri atas: (a) Kriteria ketaatan yang digunakan untuk pemeringkatan warna biru, merah dan hitam, (b) Kriteria penilaian aspek lebih dari yang dipersyaratkan (beyond compliance) untuk pemeringkatan warna hijau dan emas.

Peringkat kinerja akan diwakili dengan warna yang telah ditetapkan oleh Kementerian Lingkungan Hidup. Berdasarkan Peraturan Menteri Lingkungan Hidup No 5 tahun 2011 pasal 4, peringkat kinerja PROPER dibedakan menjadi 5 warna dengan pengertian sebagai berikut:

a. Emas, diberikan kepada penanggung jawab usaha dan/atau kegiatan yang telah konsisten menunjukkan keunggulan lingkungan (environmental excellency) dalam proses produksi dan/atau jasa, melaksanakan bisnis yang beretika dan bertanggung jawab terhadap masyarakat;

b. Hijau, diberikan kepada penanggung jawab usaha dan/atau kegiatan yang telah melakukan pengelolaan lingkungan lebih dari yang dipersyaratkan dalam peraturan (beyond compliance) melalui pelaksanaan sistem pengelolaan lingkungan, pemanfaatan sumberdaya secara efisien melalui upaya $4 \mathrm{R}$ (Reduce, Reuse, Recycle dan Recovery), dan melakukan upaya tanggung jawab sosial (CSR/ Comdev) dengan baik;

c. Biru, diberikan kepada penanggung jawab usaha dan/atau kegiatan yang telah melakukan upaya pengelolaan lingkungan yang dipersyaratkan sesuai dengan ketentuan dan/ atau peraturan perundang-undangan;

d. Merah, diberikan kepada penanggung jawab usaha dan/ atau kegiatan yang upaya pengelolaan lingkungan hidup dilakukannya tidak sesuai dengan persyaratan sebagaimana diatur dalam peraturan perundang-undangan; dan

e. Hitam, diberikan kepada penanggung jawab usaha dan/ atau kegiatan yang sengaja melakukan kelalaian yang mengakibatkan pencemaran dan/ atau kerusakan lingkungan serta pelanggaran terhadap peraturan perundang-undangan atau tidak melaksanakan sanksi administrasi.

Perusahaan PROPER dengan peringkat emas, hijau dan biru dinilai mampu untuk mengelola lingkungan dengan optimal. Menurut Flammer (2012), perusahaan yang melaporkan kinerja lingkungan secara bertanggung jawab akan meningkatkan harga saham. Oleh karena itu, peringkat PROPER emas, hijau maupun biru dinilai akan 
memberikan kenaikan harga saham. Investor akan merasa aman dalam menginvestasikan modalnya karena percaya bahwa keberlangsungan usaha perusahaan di masa mendatang terjamin. Kondisi inilah yang mendorong investor untuk menjual investasi demi mendapatkan capital gain sehingga volume perdagangan saham bertambah.

Adapun beberapa perusahaan yang meskipun sudah mengikuti program PROPER masih memperoleh peringkat merah atau hitam, sehingga menyebabkan perusahaan dinilai buruk oleh investor karena belum mampu mengelola lingkungan dengan optimal. Berdasarkan Peraturan Nomor 5 Tahun 2011 tentang Program Penilaian Peringkat Kinerja Perusahaan dalam Pengelolaan Lingkungan Hidup perusahaan yang berperingkat hitam langsung diserahkan kepada proses penegakan hukum sedangkan perusahaan yang berperingkat merah akan dimasukkan dalam pembinaan untuk perbaikan kinerja pengelolaan lingkungan. Peringkat buruk akan membuat investor menduga abnormal return akan turun dan menyebabkan volume perdagangan saham berkurang.

Reaksi Pasar. Reaksi pasar merupakan reaksi investor mengenai suatu peristiwa. Reaksi pasar dapat ditunjukkan melalui 2 (dua) indikator yaitu abnormal return dan volume perdagangan saham. Volume perdagangan saham adalah rasio antara jumlah lembar saham yang diperdagangkan pada waktu tertentu terhadap jumlah saham beredar pada waktu tertentu (Dewi 2011). Volume mencerminkan pengharapan investor individual, minat investor, serta likuiditas saham. Volume perdagangan saham diukur dengan menggunakan TVA (Trading Volume Activity).

Sedangkan abnormal return berkaitan dengan risiko investasi. Abnormal return atau excess return merupakan kelebihan dari return yang sesungguhnya terhadap return normal (Hartono 2014). Return normal adalah return ekspektasi yang diharapkan oleh investor. Penelitian ini menggunakan market adjusted model untuk mengestimasi abnormal return saham. Model ini menganggap bahwa praduga yang terbaik untuk mengestimasi return suatu sekuritas adalah return indeks pasar pada saat tersebut (saat peristiwa terjadi). Oleh karena itu, model estimasi ini tidak menggunakan periode estimasi karena return sekuritas yang diestimasi adalah sama dengan return indeks pasar.

Perbedaan Reaksi Pasar Sebelum dan Sesudah Pengumuman PROPER. Shareholders akan memberikan apresiasi kepada perusahaan yang berperingkat baik dan memberikan tekanan dan atau dorongan kepada perusahaan yang belum berperingkat baik (Sekretariatan Kementerian Lingkungan Hidup,2010). Apresiasi kepada perusahaan berperingkat baik ditandai dengan naiknya harga atau return saham. Hal ini menunjukkan bahwa semakin diminatinya saham tersebut oleh masyarakat, investor akan menjual sahamnya demi keuntungan, sehingga akan menambah volume perdagangan. Begitu pula sebaliknya, jika harga atau return saham turun, maka investor akan tidak akan menjual saham sehingga volume perdagangan saham berkurang.

Kinerja perusahaan dalam menciptakan lingkungan yang baik diukur melalui Program Penilaian Peringkat Kinerja Perusahaan dalam Pengelolaan Lingkungan Hidup (PROPER). Penggunaan warna dalam peringkat PROPER serta pengungkapan keputusan Kementerian Lingkungan Hidup merupakan suatu bentuk komunikatif penyampaian kinerja kepada masyarakat yang kemudian menjadi suatu sinyal bagi para pelaku pasar untuk mengambil keputusan investasi. PROPER merupakan informasi bagi investor karena PROPER mencerminkan kinerja lingkungan suatu perusahaan. Perusahaan diharapkan akan terbebas dari kasus pencemaran sehingga keberlangsungan perusahaan di 
masa mendatang terjamin. Jika perusahaan mengikuti PROPER dan mendapat peringkat baik, maka abnormal return cenderung naik dan volume perdagangan saham bertambah.

Peneliti terdahulu juga meneliti reaksi pasar oleh investor tetapi untuk penghargaan yang berbeda. Budiman dan Supatmi (2009) menyimpulkan bahwa pasar bereaksi terhadap pengumuman Indonesia Sustainability Reporting Award (ISRA) periode 20052008. Prabandari dan Suryanawa (2014) menemukan bahwa environmental performance berpengaruh positif pada reaksi investor di perusahaan high profile Bursa Efek Indonesia (BEI) periode 2008-2012.

Adapun penelitian oleh Widarwati dan Lisviani (2015) menyimpulkan bahwa perkembangan return saham perusahaan PROPER dan Non PROPER di setiap tahunnya mengalami fluktuasi. Penelitian diuji dengan menggunakan uji t dan ditemukan bahwa terdapat perbedaan rata-rata return saham perusahaan PROPER dengan perusahaan Non PROPER.

Penelitian ini menguji beda reaksi pasar pada periode sebelum dan sesudah pengumuman PROPER. PROPER memberikan informasi kepada investor mengenai kondisi perusahaan dalam pengelolaan lingkungan hidupnya dalam pengambilan keputusan investasi. Investor melakukan analisis abnormal return dan volume perdagangan saham. PROPER mengindikasikan kinerja dan prospek perusahaan bagus sehingga akan memberikan kecenderungan naiknya abnormal return sehingga volume akan bertambah dibandingkan dengan periode sebelumnya. Oleh karena itu, diajukan hipotesis seperti ini:

H1: Terdapat perbedaan abnormal return sebelum dan sesudah pengumuman PROPER.

$\mathrm{H} 2$ : Terdapat perbedaan volume perdagangan saham sebelum dan sesudah pengumuman

Perbedaan Reaksi Pasar Antar Peringkat PROPER. Peringkat PROPER yang diwakili oleh warna tertentu dapat menimbulkan perbedaan reaksi pasar. Peringkat baik diwakili oleh warna emas, hijau dan biru dinilai sudah memenuhi kriteria ketaatan yang ada, sehingga perusahaan dinilai mampu dan akan meningkatkan citra baik. Ketaatan juga akan menghindarkan perusahaan dari kasus hukum sehingga keberlangsungan usaha lebih terjamin. Hal tersebut akan menjadi good news bagi investor dan menimbulkan reaksi pasar yaitu naiknya harga saham dan volume perdagangan saham.

Sedangkan untuk peringkat buruk diwakili oleh warna merah dan hitam yang diduga akan menimbulkan reaksi pasar yang berbeda. Perusahaan dianggap mencemari lingkungan dan bisa saja timbul kasus hukum atas pencemaran yang ada sehingga brand menjadi jelek di mata masyarakat. Hal ini merupakan indikasi yang buruk bagi investor, maka investor menduga bahwa harga saham turun sehingga investor tidak memperdagangkan sahamnya yang berakibat pada berkurangnya volume perdagangan saham. Oleh karena itu, peneliti dapat menambahkan dua hipotesis selanjutnya yang menguji reaksi pasar antara peringkat PROPER baik dan buruk yaitu:

H3: Terdapat perbedaan abnormal return antar peringkat PROPER.

H4: Terdapat perbedaan volume perdagangan saham antar peringkat PROPER.

\section{METODE}


Jenis dan Sumber Data. Data penelitian berasal dari data sekunder. Data tersebut berupa data perusahaan yang terdaftar PROPER, tanggal pengumuman peringkat PROPER, harga saham harian perusahaan, dan volume perdagangan saham. Data mengenai saham dapat diperoleh dari situs www.idx.co.id dan finance.yahoo.com. Sedangkan data mengenai perusahaan PROPER beserta peringkatnya diperoleh dari Keputusan Menteri Lingkungan Hidup melalui situs www.menlh.go.id, serta pengumuman PROPER dari Sekretariatan Kementerian Lingkungan Hidup.

Populasi dan Penarikan Sampel. Populasi dalam penelitian ini adalah perusahaanperusahaan PROPER yang listing di Bursa Efek Indonesia (BEI) pada tahun 2009 sampai dengan tahun 2013. Cara pemilihan sampel dilakukan dengan metode purposive sampling. Perusahaan dipilih menurut kriteria tertentu, di mana perusahaan yang dijadikan sampel merupakan perusahaan-perusahaan yang mengikuti PROPER dan listing di BEI selama 5 tahun berturut-turut dan tidak melakukan corporate action selama periode pengamatan, hal ini dilakukan karena 5 tahun merupakan waktu yang cukup panjang untuk penelitian dan diharapkan lebih mencerminkan kondisi pasar yang sebenarnya, serta untuk mengetahui perubahan peringkat PROPER perusahaan selama 5 tahun.

Teknik Analisis. Teknik analisis data yang digunakan dalam penelitian ini adalah teknik analisis event study yang bertujuan untuk menganalisis perbedaan abnormal return dan volume perdagangan saham pada periode sebelum dan sesudah pengumuman peringkat PROPER. Jika suatu informasi diumumkan maka diharapkan pasar akan bereaksi ketika pengumuman diterima oleh pasar. Periode penelitian yang digunakan untuk menganalisis reaksi pasar adalah 3 hari sebelum dan sesudah pengumuman PROPER.

Alat Pengujian Hipotesis. Model estimasi yang dipilih untuk penelitian ini adalah market-adjusted model return, di mana model ini tidak memerlukan periode estimasi karena menganggap return sekuritas yang diestimasi adalah sama dengan return indeks pasar. Menurut Hartono (2014), tahapan untuk menghitung abnormal return sebagai berikut:

1. Menghitung Actual Return (Return Sebenarnya). Actual return dihitung dengan menggunakan persamaan:

$$
R(i t)=\frac{P(i t)-P i(t-1)}{P i(t-1)}
$$

Keterangan: R (it) : actual return pada hari t; $\mathrm{P}$ (it) : harga penutupan saham pada hari t; $\mathrm{Pi}(\mathrm{t}-1)$ : harga penutupan saham pada hari $\mathrm{t}-1$.

2. Menghitung Expected Return (Return Ekspektasi). Expected return diasumsikan sama dengan market return pada hari $\mathrm{t}$ dan dihitung dengan menggunakan persamaan:

$$
\operatorname{Rm}(\mathrm{t})=\frac{\operatorname{IHSG}(\mathrm{t})-\operatorname{IHSG}(\mathrm{t}-1)}{\operatorname{IHSG}(\mathrm{t}-1)}
$$

Keterangan: Rm (t) : market return pada hari t; IHSG (t): Indeks Harga Saham Gabungan pada hari t; IHSG(t-1): Indeks Harga Saham Gabungan pada hari t-1.

3. Menghitung Abnormal return. Abnormal return dihitung dengan menggunakan persamaan: 


$$
\mathrm{AR}(\mathrm{it})=\mathrm{R}(\mathrm{it})-\mathrm{ER}(\mathrm{it})
$$

Keterangan: AR(it) = abnormal return saham pada hari $\mathrm{t}$; $\mathrm{R}(\mathrm{it})$ = actual return saham pada hari $\mathrm{t} ; \mathrm{ER}(\mathrm{it})=$ expected return saham pada hari $\mathrm{t}$

Selain abnormal return, reaksi pasar terhadap volume perdagangan saham (Trading Volume Activity/ TVA). Menurut Winarto dan Nugrahanti (2013), TVA dapat dihitung dengan menggunakan rumus:

$$
\text { TVA } \mathrm{i}=\frac{\Xi \text { saham perusahaan } k e-i \text { yang diperdagangkan dalam waktu } \tau}{\varepsilon \text { saham perusahaan ke-i yang beredar dalam waktu } t}
$$

Setelah TVA diketahui maka dihitung rata-rata TVA selama periode pengamatan dengan rumus:

$$
\text { XTVAt }=\frac{\varepsilon T V A i}{n}
$$

Keterangan: XTVAt : rata-rata TVA pada waktu ke-t; TVA : TVA pada waktu ke-t $\mathrm{N}$ : jumlah sampel.

Metode Analisis. Penelitian mengenai perbedaan reaksi pasar sebelum dan sesudah pengumuman PROPER dan antar peringkat PROPER terlebih dahulu diuji normalitas. Jika data berdistribusi normal maka peneliti menggunakan metode analisis statistik yaitu ttest. Jika data tidak berdistribusi normal maka peneliti menggunakan metode analisis statistik yaitu Wilcoxon Signed Test. Kedua metode analisis statistik tersebut digunakan untuk menguji data berpasangan di mana dua sampel penelitian saling berkaitan satu sama lain.

\section{HASIL DAN PEMBAHASAN}

Proses Pengambilan Sampel. Populasi penelitian adalah perusahaan yang terdaftar di BEI dan mengikuti PROPER tahun 2009 sampai 2013. Populasi berjumlah 39 perusahaan dan tersisa 25 perusahaan yang memenuhi kriteria peneliti. Penentuan sampel dapat dilihat pada Tabel 1.

Tabel 1. Proses Pengambilan Sampel

\begin{tabular}{clc}
\hline No. & \multicolumn{1}{c}{ Kriteria } & Jumlah \\
\hline 1 & $\begin{array}{l}\text { Perusahaan yang mengikuti PROPER dan listing di BEI selama 5 } \\
\text { tahun berturut-turut }\end{array}$ & 39 \\
2 & $\begin{array}{l}\text { Perusahaan yang melakukan corporate action selama periode } \\
\text { pengamatan }\end{array}$ & Jumlah Sampel Penelitian \\
\hline
\end{tabular}

Total sampel penelitian untuk 1 tahun adalah 25 perusahaan, sehingga untuk periode 5 tahun adalah 125 data (5 tahun x 25 perusahaan). 
Analisis Deskriptif. Statistik Deskriptif Abnormal Return dan Volume Perdagangan Saham. Berikut ini adalah Tabel 2 yang menjelaskan nilai deskriptif meliputi nilai minimum, maksimum, dan mean abnormal return serta volume perdagangan saham sebelum dan sesudah pengumuman PROPER selama 5 tahun.

Tabel 2. Statistik Deskriptif Abnormal Return dan TVA

\begin{tabular}{|c|c|c|c|c|c|c|}
\hline \multirow{2}{*}{ Variabel } & \multicolumn{3}{|c|}{ Sebelum } & \multicolumn{3}{c|}{ Sesudah } \\
\cline { 2 - 7 } & Min. & Max. & Mean & Min. & Max. & Mean \\
\hline $\begin{array}{c}\text { Abnormal } \\
\text { Return }\end{array}$ & $-0,11421$ & 0,05816 & $-0,0055626$ & $-0,02618$ & 0,15347 & 0,0042604 \\
\hline TVA & 0,00000 & 0,04273 & 0,0025066 & 0,00000 & 0,09421 & 0,0023863 \\
\hline
\end{tabular}

Sumber: Data diolah (2015)

Berdasarkan Tabel 2, nilai rata-rata abnormal return mengalami kenaikan sebesar 0,009823. Hal ini menandakan bahwa ekspektasi investor terhadap naiknya harga saham benar adanya. Risiko investasi yang berkurang akan menyebabkan perusahaan berprospek bagus, sehingga harga saham akan naik. Selain itu, nilai mean TVA sebelum dan sesudah pengumuman justru mengalami penurunan sebesar 0,0001203. Hal ini dimungkinkan oleh faktor lain seperti investor berpikir bahwa return akan semakin naik sehingga investor tidak mau menjualnya terlebih dahulu demi mendapatkan capital gain yang lebih besar di periode selanjutnya. Oleh karena itu volume perdagangan saham berkurang karena investor tidak memperdagangkan sahamnya.

Abnormal Return Sebelum dan Sesudah Pengumuman PROPER. Grafik 1 di bawah ini mengambarkan pergerakan rata-rata abnormal return 3 hari sebelum dan 3 hari sesudah pengumuman PROPER selama 5 tahun.

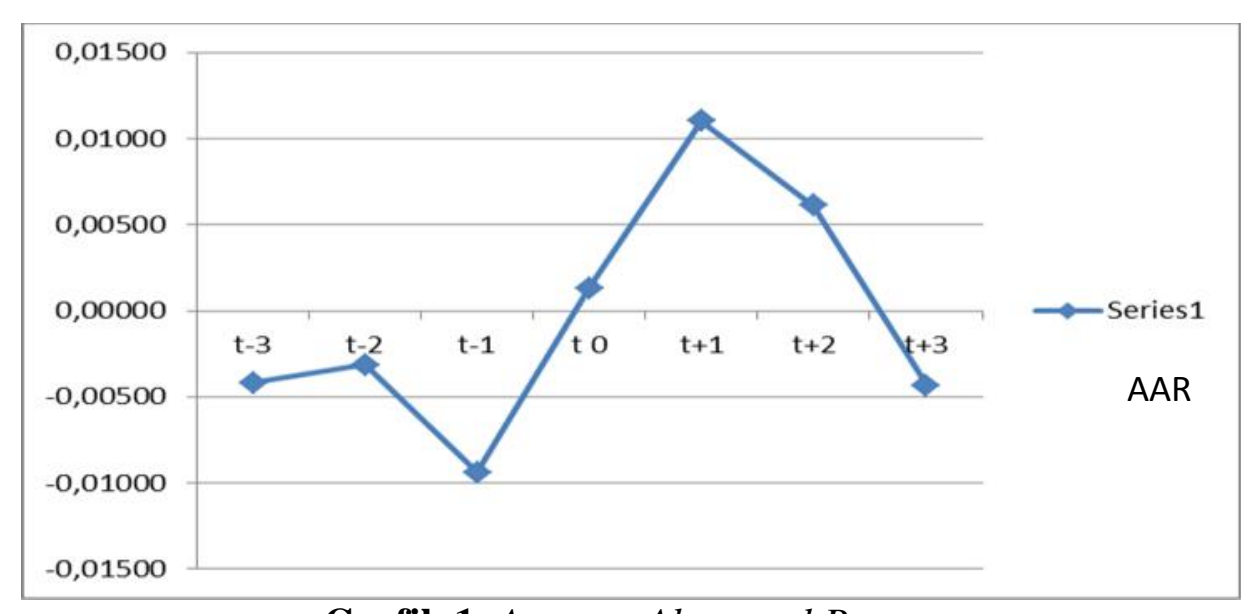

Grafik 1. Average Abnormal Return

Sumber: Data diolah (2015)

Data-data yang telah diolah memperlihatkan hasil bahwa rata-rata abnormal return pada t-3 hingga t-1 memiliki nilai negatif selama 5 tahun di mana titik terendah berada pada $\mathrm{t}-1$ 
yaitu -0,00938. Kondisi tersebut mencerminkan bahwa tidak adanya ekspektasi yang diharapkan dari investor karena investor tidak mengharapkan adanya return dan menduga bahwa investasi mereka mengalami kerugian. Namun pada t 0 (periode pengumuman PROPER), rata-rata abnormal return mengalami kenaikan menjadi 0,00133. Pengumuman PROPER dianggap sebagai news karena perusahaan diindikasikan cinta lingkungan, kinerja lingkungan bagus, serta prospek perusahaan di masa depan baik sehingga pada $t+1$ sesudah pengumuman PROPER, abnormal return memiliki nilai tertinggi sebesar 0,01101, meskipun pada $\mathrm{t}+2$ dan $\mathrm{t}+3$ abnormal return mengalami penurunan kembali.

Volume Perdagangan Saham Sebelum dan Sesudah Pengumuman PROPER. Berikut ini adalah grafik 2 yang memuat pergerakan rata-rata trading volume activity sebelum dan sesudah pengumuman PROPER selama 5 tahun.

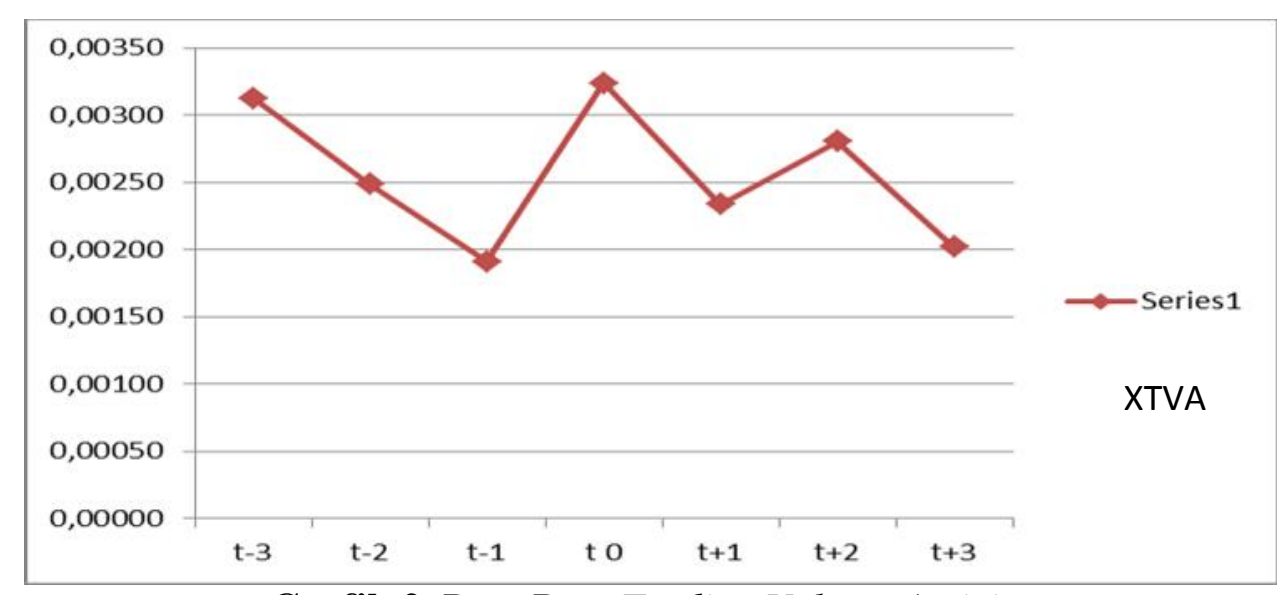

Grafik 2. Rata-Rata Trading Volume Activity

Sumber: Data diolah (2015

Rata-Rata TVA pada periode sebelum dan sesudah pengumuman PROPER tidak terlalu berfluktuasi seperti rata-rata abnormal return. Tabel di atas menjelaskan bahwa rata-rata TVA tertinggi pada t 0 yaitu 0,00324 , di mana kondisi ini mencerminkan bahwa sahamsaham aktif diperdagangkan di pasar modal pada pengumuman PROPER. Investor mudah dalam menjual investasi mereka demi capital gain sehingga menyebabkan volume perdagangan saham bertambah. Rata-rata TVA terlihat menurun ketika t-3 sampai t-1. Titik terendah berada pada t-1 dengan angka sebesar 0,00191. Sedangkan rata-rata TVA menurun kembali pada titik $\mathrm{t}+1$ tapi kembali naik pada $\mathrm{t}+2$ sebesar 0,00280 , meskipun pada akhirnya kembali menurun pada $\mathrm{t}+3$.

Abnormal Return Antar Peringkat PROPER. Grafik 3 mengambarkan pergerakan ratarata abnormal return antar peringkat PROPER selama 5 tahun, tetapi sampel yang digunakan oleh peneliti merupakan perusahaan-perusahaan yang pernah mendapat peringkat PROPER yang baik maupun buruk. Oleh karena itu hanya ada 8 perusahaan yang menjadi sampel seperti yang dapat dilihat pada grafik. 


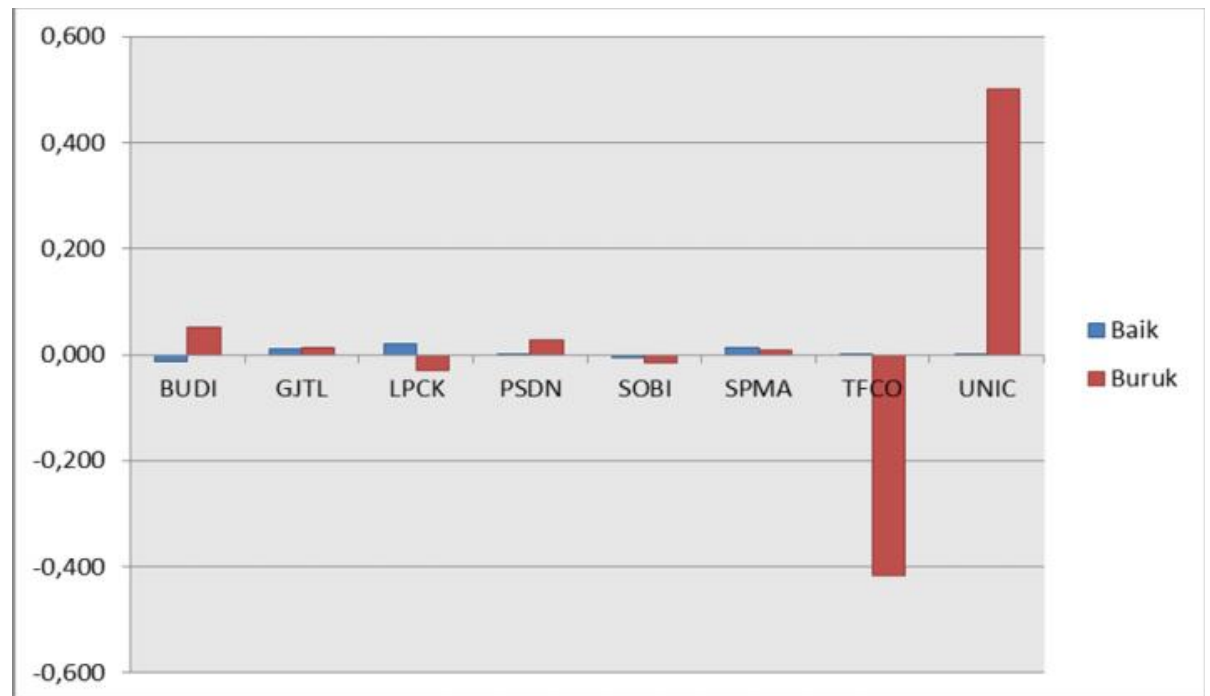

Grafik 3. Average Abnormal Return Berdasarkan Peringkat PROPER Sumber: Data diolah (2015)

Tabel 3 memuat nilai abnormal return dari 8 perusahaan sampel yang memiliki peringkat baik dan buruk.

Tabel 3. Average Abnormal Return Berdasarkan Peringkat PROPER

\begin{tabular}{ccc}
\hline \multirow{2}{*}{ Perusahaan } & \multicolumn{2}{c}{ Abnormal Return } \\
\cline { 2 - 3 } & Baik & Buruk \\
\hline BUDI & $-0,01298$ & 0,05088 \\
GJTL & 0,011752 & 0,013707 \\
LPCK & 0,020003 & $-0,03053$ \\
PSDN & 0,001692 & 0,02739 \\
SOBI & $-0,00551$ & $-0,01540$ \\
SPMA & 0,012388 & 0,00841 \\
TFCO & 0,001631 & $-0,41737$ \\
UNIC & 0,001631 & 0,49985 \\
\hline
\end{tabular}

Sumber: Data diolah (2015)

Abnormal return untuk PT Gajah Tunggal Tbk (GJTL), PT Prasidha Aneka Niaga Tbk (PSDN), Sorini Corporation (SOBI), serta PT Suparma Tbk (SPMA) tidak terlalu berbeda jauh. PT Budi Starch \& Sweetener Tbk (BUDI) justru memiliki nilai abnormal return negatif ketika perusahaan memperoleh peringkat PROPER yang baik. Sedangkan untuk PT Lippo Cikarang Tbk (LPCK) dan PT Tifico Fiber Indonesia Tbk (TFCO) memiliki abnormal return negatif ketika perusahaan memperoleh peringkat yang buruk. PT Tifico Fiber Indonesia Tbk memiliki abnormal return terendah sebesar -0,41737 akibat peringkat PROPER yang buruk. Selain itu, faktor lain mempengaruhi rendahnya return PT Tifico Fiber Indonesia Tbk adalah pada tahun 2012 perusahaan memprediksikan bahwa perusahaan pesimis untuk mencapai target pendapatan yang lebih tinggi pada tahun 2013 akibat biaya produksi yang tinggi dan daya beli masyarakat menurun. Peringkat yang 
buruk serta adanya dugaan penurunan kinerja perusahaan mungkin merupakan penyebab abnormal return rendah.

Sedangkan abnormal return tertinggi akibat peringkat PROPER yang baik dicetak oleh PT Lippo Cikarang Tbk yaitu 0,020003. Abnormal return PT Lippo Cikarang Tbk berkurang dan menjadi negatif akibat adanya suspensi dari BEI karena kenaikan harga saham perusahaan dinilai tidak wajar. Akibat dari penghentian tersebut maka harga saham PT Lippo Cikarang mengalami penurunan. PT Unggul Indah Cahaya Tbk (UNIC) memiliki abnormal return tertinggi walaupun peringkat PROPER-nya buruk sebesar 0,49985. PT Unggul Indah Cahaya Tbk tetap dapat memperoleh abnormal return tertinggi karena ada kemungkinan perusahaan memiliki faktor lain yang membuat perusahaan tetap baik di mata investor, seperti keputusan jangka panjang dengan membangun office tower demi memasuki dunia properti, membayar obligasi senilai Rp 448 M, selain itu laba bersih konsolidasi naik sebesar $4,7 \%$.

Volume Perdagangan Saham Antar Peringkat PROPER. Grafik 4 memuat pergerakan rata-rata Trading Volume Activity (TVA) antar peringkat PROPER selama 5 tahun. Sampel penelitian sama dengan sampel penelitian pada grafik 4.

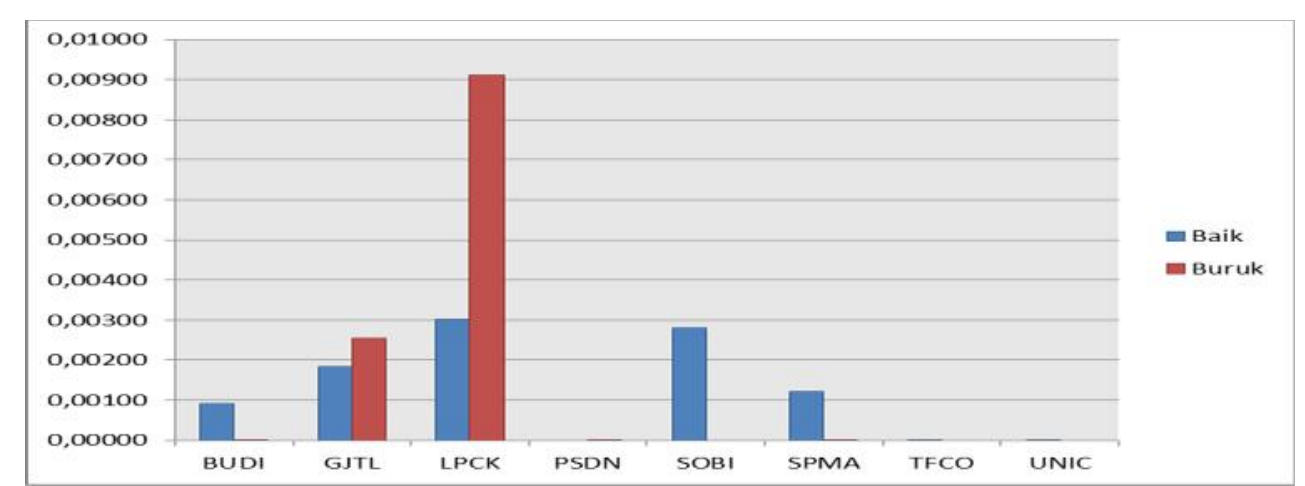

Grafik 4. Rata-Rata Trading Volume Activity Berdasarkan Peringkat PROPER Sumber: Data diolah (2015)

Tabel 4 memuat nilai rata-rata TVA dari 8 perusahaan sampel yang memiliki peringkat baik dan buruk.

Tabel 4. Rata-Rata Trading Volume Activity Berdasarkan Peringkat PROPER

\begin{tabular}{ccc}
\hline \multirow{2}{*}{ Perusahaan } & \multicolumn{2}{c}{ TVA } \\
\cline { 2 - 3 } & 0,00092 & 0,00000 \\
BUDI & 0,00185 & 0,00255 \\
GJTL & 0,00303 & 0,00912 \\
LPCK & 0,00000 & 0,00000 \\
PSDN & 0,00281 & 0,00000 \\
SOBI & 0,00122 & 0,00000 \\
SPMA & 0,00000 & 0,00000 \\
TFCO & 0,00000 & 0,00000 \\
UNIC
\end{tabular}

Sumber: Data diolah (2015) 
Volume perdagangan saham PT Budi Starch \& Sweetener Tbk (BUDI), PT Gajah Tunggal Tbk (GJTL), PT Lippo Cikarang Tbk (LPCK), Sorini Corporation (SOBI), dan PT Suparma Tbk (SPMA) memiliki nilai lebih dari 0,009. Volume perdagangan saham perusahaan berperingkat PROPER baik memiliki nilai tertinggi yaitu 0,00303 yang diperoleh oleh PT Lippo Cikarang Tbk dikarenakan investor menjual saham demi mendapatkan gain sehingga saham menjadi likuid dan menambah volume perdagangan saham. Selain didukung dengan peringkat PROPER yang baik, setiap tahun PT Lippo Cikarang Tbk dan induknya, Lippo Karawaci memiliki kinerja keuangan yang selalu memuaskan. Laba bersih dan surplus berhasil diperoleh oleh PT Lippo Cikarang Tbk, selain strategi bisnis perusahaan ini dirasa cukup menarik untuk dikembangkan dalam jangka panjang.

Namun sebenarnya volume perdagangan saham tertinggi adalah ketika PT Lippo Cikarang Tbk memperoleh peringkat PROPER yang buruk dengan angka 0,00912. Para investor PT Lippo Cikarang Tbk seharusnya tidak aktif memperdagangkan sahamnya karena diduga akan mengalami loss. Walaupun peringkat PROPER buruk, rencana jangka panjang PT Lippo Cikarang Tbk dianggap baik sehingga prospek perusahaan baik di masa depan mampu merangsang investor untuk menjual sahamnya yang pada akhirnya menambah volume perdagangan saham.

\section{Pengujian Normalitas}

Pengujian normalitas dengan menggunakan Kolmogorov-Smirnov menunjukan bahwa data abnormal return sebelum dan sesudah pengumuman PROPER memiliki nilai signifikansi sebesar 0,000 dan 0,000. Sedangkan untuk Trading Volume Activity, data memiliki nilai signifikansi sebesar 0,000 dan 0,000 . Hal ini berarti nilai probabilitas kedua variabel lebih kecil dari tingkat signifikansi 5\% dan disimpulkan bahwa data tidak berdistribusi normal.

Selain uji normalitas untuk kedua data di atas, adapun data AAR untuk peringkat PROPER yang baik dan buruk memiliki nilai signifikansi 0,200 dan 0,015. Rata-Rata TVA untuk peringkat PROPER yang baik dan buruk memiliki nilai signifikansi sebesar 0,200 dan 0,000 . Hal ini mencerminkan bahwa data untuk peringkat PROPER yang baik (emas, hijau dan biru) berdistribusi normal karena nilai probabilitasnya memiliki nilai yang lebih besar dari tingkat signifikansi 5\%, tetapi hal ini bertolak belakang dengan data untuk peringkat PROPER yang buruk (merah dan hitam) karena data tidak berdistribusi normal. Keempat data yang tidak berdistribusi dengan normal pada akhirnya diuji dengan Wilcoxon Signed Test karena sampel penelitian saling berkaitan satu sama lain (dependen).

Pengujian Hipotesis. Abnormal Return Sebelum dan Sesudah Pengumuman PROPER. Pengujian terhadap H1 dengan menggunakan Wilcoxon Signed Test dengan tingkat signifikansi $5 \%$.

Tabel 5. Ringkasan Hasil Pengujian Hipotesis Pertama

\begin{tabular}{cccc}
\hline Keterangan & Z & Assym. Sig. (2-tailed) & Hasil Uji \\
\hline AAR Sebelum - AAR Sesudah & $-3,259$ & 0,001 & H1 diterima \\
$\mathrm{t}-3-\mathrm{t}+3$ & $-0,713$ & 0,476 & H1 ditolak \\
$\mathrm{t}-2-\mathrm{t}+2$ & $-2,211$ & 0,027 & H1 diterima \\
$\mathrm{t}-1-\mathrm{t}+1$ & $-3,356$ & 0,001 & H1 diterima \\
\hline
\end{tabular}

Sumber: Data diolah (2015) 
Berdasarkan Tabel 5, ditemukan bahwa probabilitas untuk periode sebelum dan sesudah pengumuman PROPER memiliki nilai lebih kecil dibanding tingkat signifikansi $5 \%$, sehingga hal ini berarti bahwa $\mathrm{H} 1$ diterima. Namun ketika t-3 dibandingkan dengan $\mathrm{t}+3$, probabilitasnya lebih besar daripada tingkat signifikansi yang mengakibatkan $\mathrm{H} 1$ ditolak. H1 ditolak dikarenakan rata-rata abnormal return pada titik t-3 dan $\mathrm{t}+3$ tidak terlalu berbeda jauh dan memiliki nilai yang negatif (dapat dilihat pada tabel 1). Nilai ratarata pada $\mathrm{t}-3$ adalah $-0,00419$ sedangkan nilai pada $\mathrm{t}+3$ adalah $-0,00432$.

Uji statistik membuktikan bahwa hipotesis mengenai perbedaan abnormal return sebelum dan sesudah pengumuman PROPER diterima. Adanya perbedaan abnormal return menandakan bahwa ekspektasi investor akan berubah ketika diberikan informasi penting pada pengumuman PROPER. PROPER merupakan penghargaan yang diberikan oleh pemerintah Indonesia, di mana jika perusahaan peserta meraih peringkat emas, hijau dan biru dinyatakan baik dalam pengelolaan lingkungannya dan dimungkinkan bebas dari kasus pencemaran. Oleh karena itu, investor akan berinvestasi demi memperoleh capital gain.

Hasil penelitian ini sejalan dengan hasil penelitian Budiman dan Supatmi (2009) serta Widarwati dan Lisviani (2015) yang menemukan bahwa para investor merespon atas pengumuman ISRA (Indonesia Sustainability Reporting Award) 2005-2008 dan untuk perusahaan PROPER, Non PROPER, serta antar PROPER.

Trading Volume Activity Sebelum dan Sesudah Pengumuman PROPER. Pengujian terhadap H2 dengan menggunakan Wilcoxon Signed Test dengan tingkat signifikansi 5\% daapt dilihat pada Tabel 6.

Tabel 6. Ringkasan Hasil Pengujian Hipotesis Kedua

\begin{tabular}{cccc}
\hline Keterangan & Z & Assym. Sig. (2-tailed) & Hasil Uji \\
\hline TVA Sebelum - TVA Sesudah & $-1,243$ & 0,297 & H2 ditolak \\
$\mathrm{t}-3-\mathrm{t}+3$ & $-0,463$ & 0,643 & H2 ditolak \\
$\mathrm{t}-2-\mathrm{t}+2$ & $-1,904$ & 0,057 & H2 ditolak \\
$\mathrm{t}-1-\mathrm{t}+1$ & $-0,425$ & 0,671 & H2 ditolak \\
\hline
\end{tabular}

Sumber: Data diolah (2015)

Berdasarkan Tabel 6, ditemukan bahwa probabilitas pada sebelum pengumuman PROPER (t-3 dan t-2) memiliki nilai lebih besar dibanding tingkat signifikansi 5\%, sehingga hal ini berarti bahwa $\mathrm{H} 2$ ditolak. Hal ini berarti tidak terdapat perbedaan yang signifikan untuk volume perdagangan saham sebelum dan sesudah pengumuman PROPER. Tidak adanya perbedaan volume perdagangan dimungkinkan akibat investor menjual saham kemudian saham mereka dibeli dalam jumlah lembar saham yang sama. Selain itu investor dimungkinkan terlambat dalam merespon pengumuman PROPER, sehingga walaupun abnormal return tinggi, investor tidak mengetahuinya. Investor mengetahui good news ini setelah PROPER diumumkan beberapa hari sesudahnya, sehingga menyebabkan investor tidak mendapatkan saham yang pada akhirnya mengakibatkan volume perdagangan saham tidak berbeda. Hasil penelitian ini bertolak belakang dengan hasil penelitian Linuwih dan Nugrahanti (2014) yang menemukan bahwa ada perbedaan volume perdagangan saham karena investor merespon atas pengumuman ISRA 2009-2011. 
Abnormal Return Antar Peringkat PROPER. Pengujian terhadap H3 dengan menggunakan Wilcoxon Signed Test dengan tingkat signifikansi 5\%.

Tabel 7. Ringkasan Pengujian Hipotesis Ketiga

\begin{tabular}{lccc}
\hline \multicolumn{1}{c}{ Keterangan } & Z & Assym. Sig. (2-tailed) & Hasil Uji \\
\hline $\begin{array}{l}\text { AR Peringkat Baik - AR Peringkat } \\
\text { Buruk }\end{array}$ & $-0,140$ & 0,889 & H3 ditolak \\
\hline
\end{tabular}

Sumber: Data diolah (2015)

Berdasarkan Tabel 7, ditemukan bahwa tidak ada perbedaan abnormal return antar peringkat PROPER yaitu antara peringkat PROPER baik dan buruk. Nilai probabilitas sebesar 0,889 melebihi batas signifikansi 5\% yang menyebabkan H3 ditolak. Hasil hipotesis ini bertolak belakang dengan $\mathrm{H} 1$, di mana terdapat perbedaan abnormal return sebelum dan sesudah pengumuman PROPER. Investor seharusnya berekspektasi akan mendapatkan return yang lebih tinggi jika perusahaan memperoleh peringkat yang baik. Tetapi setelah diuji lebih lanjut, perolehan peringkat baik dan buruk bukan informasi penting bagi investor karena investor ada yang tetap memilih untuk berinvestasi di perusahaan PROPER yang buruk (dapat dilihat pada grafik 3). Investor mungkin kurang memahami dampak dan prospek perusahaan di masa mendatang akibat perolehan peringkat PROPER. Investor tetap berinvestasi pada perusahaan PROPER buruk karena tidak mengetahui prospek buruk seperti rawan terkena kasus pencemaran atau mungkin dipengaruhi oleh faktor lain, seperti mempertimbangkan strategi jangka panjang dan track record yang baik selama perusahaan PROPER buruk menjalankan aktivitas operasionalnya.

Hasil penelitian ini konsisten dengan hasil penelitian Siska (2012) yang menemukan bahwa pasar tidak bereaksi ketika diberikan pengumuman Annual Reporting Award (ARA). Namun bertolak belakang dengan hasil penelitian Widiarwati dan Lisviani (2015) serta Wiranata dan Wirajaya (2012) yang menemukan bahwa investor merespon atas perusahaan PROPER, Non PROPER, dan antar PROPER dan di seputar pengumuman PROPER.

Trading Volume Activity Antar Peringkat PROPER. Pengujian terhadap H4 dengan menggunakan Wilcoxon Signed Test dengan tingkat signifikansi 5\%.

Tabel 8. Ringkasan Pengujian Hipotesis Keempat

\begin{tabular}{cccc}
\hline Keterangan & Z & Assym. Sig. (2-tailed) & Hasil Uji \\
\hline TVA Peringkat Baik - TVA Peringkat & $-0,405$ & 0,686 & H4 ditolak
\end{tabular}

Buruk

Sumber: Data diolah (2015)

Berdasarkan Tabel 8, ditemukan bahwa tidak ada perbedaan Trading Volume Activity antar peringkat PROPER yaitu antara peringkat PROPER baik dan buruk. H4 ditolak karena probabilitas data sebesar 0,686 lebih besar dibandingkan dengan nilai signifikansi $5 \%$. Volume saham-saham tidak terlalu berbeda jauh ketika diperdagangkan di bursa modal. Perusahaan PROPER dengan peringkat yang baik aktif diperdagangkan. Oleh karena itu investor menjual sahamnya sehingga volume perdagangan saham bertambah. Peringkat PROPER yang buruk seharusnya menjadikan saham tidak aktif untuk 
diperdagangkan karena investor tidak akan menjual sahamnya supaya tidak mengalami kerugian.

Tetapi, perusahaan PROPER buruk juga aktif diperdagangkan di pasar modal (seperti yang dapat dilihat pada grafik 4). Faktor lain seperti strategi jangka panjang dan prospek perusahaan di masa mendatang bagus, sehingga investor juga memperdagangkan sahamnya dan menambah volume perdagangan saham. Oleh karena itu tidak ditemukan perbedaan volume perdagangan saham yang signifikan antara peringkat yang baik dan buruk.

Hasil penelitian ini sejalan dengan hasil penelitian Budiman dan Supatmi (2009) yang menemukan bahwa investor tidak merespon atas pengumuman ISRA 2005-2008. Namun bertolak belakang dengan hasil penelitian Linuwih dan Nugrahanti (2014) yang menemukan bahwa investor merespon atas pengumuman ISRA 2009-2011.

\section{PENUTUP}

Simpulan. Berdasarkan hasil dan pembahasan dengan Wilcoxon Signed Test maka dapat disimpulkan bahwa terdapat perbedaan abnormal return sebelum dan sesudah pengumuman PROPER. Peneliti juga menemukan bahwa tidak terdapat perbedaan volume perdagangan saham sebelum dan sesudah pengumuman PROPER, abnormal return antar peringkat PROPER, serta volume perdagangan saham antar peringkat PROPER.

Implikasi Penelitian. Secara teoretis, penelitian ini sejalan dengan teori sinyal karena pengumuman PROPER merupakan informasi bagi investor yang ditujukan melalui respon investor terhadap pasar modal. Salah satu manfaat bagi perusahaan adalah PROPER memberikan dampak positif untuk perusahaan. Perusahaan diharapkan mampu mempertahankan kinerja lingkungan karena hal tersebut membuat investor akan berinvestasi di perusahaan. Investor seharusnya berinvestasi pada perusahaan yang mengikuti PROPER karena perusahaan dianggap akan terbebas dari kasus pencemaran sehingga akan menaikkan return dan menambah volume perdagangan saham.

Keterbatasan dan Saran Penelitian. Penelitian ini masih mempunyai keterbatasan yaitu sampel yang digunakan untuk penelitian perbedaan reaksi pasar sebelum dan sesudah pengumuman PROPER berjumlah 25 perusahaan, sedangkan untuk penelitian reaksi pasar antar peringkat PROPER hanya berjumlah 8 perusahaan. Oleh karena itu, saran yang dapat digunakan dalam penelitian mendatang adalah lebih berfokus dalam menentukan periode penelitian agar dapat memperoleh sampel penelitian yang lebih banyak. Hal ini dikarenakan sebagian besar perusahaan go public mengikuti PROPER pada tahun 2010 dan tahun 2011, sehingga menyebabkan peneliti tidak bisa mengambil perusahaan tersebut sebagai sampel penelitian untuk periode 5 tahun (tahun 2009-2013).

\section{DAFTAR RUJUKAN}

Adi, I Kustini Indah. (2013) Pengaruh Profitabilitas, Risiko Finansial dan Keputusan Investasi terhadap Nilai Perusahaan. E print UNY. Yogyakarta.

Bandi dan Jogiyanto Hartono. (2000) "Perilaku Reaksi harga dan Volume Perdagangan Saham". Jurnal Riset Akuntansi Indonesia, 3 (2)

Berita Jateng. (2015) Pencemaran Limbah, Sido Muncul Terancam Sanksi Berat. Available at http://beritajateng.net. Diakses pada 7 Februari 2015 pukul 19.25. 
Besley dan Brigham. (2008) Definisi Teori Sinyal. Available at http://ioaddakhil.blogspot.co.id. Diakses pada 17 Oktober 2015 pukul 20.32.

Budiman dan Supatmi. (2009) "Pengaruh Pengumuman Indonesia Sustainability Reporting Award (ISRA) terhadap Abnormal Return dan Volume Perdagangan Saham (Studi Kasus pada Perusahaan Pemenang ISRA Periode 2005-2008)". Simposium Nasional Akuntansi (SNA) XII. Palembang.

Dewi, Komang Ayu Setia. (2011) "Perbedaan Volume Perdagangan Saham Sebelum dan Sesudah Reverse Stock Split pada Perusahaan yang Terdaftar di BEI Periode 20072011”. Skripsi, Fakultas Ekonomi Universitas Udayana (Unud) Bali.

Flammer, Caroline. (2010) Corporate Social Responsibility and Stock Prices: The Environmental Awareness of Shareholders. MIT Sloan School of Management Cambridge.

Hartono, Jogiyanto. (2010) Teori Portofolio dan Analisis Investasi Edisi Ketujuh. BPFE UGM: Yogyakarta.

Hartono, Jogiyanto. (2014) Teori Portofolio dan Analisis Investasi Edisi Kedelapan. BPFE UGM: Yogyakarta.

Hendrawaty, Jessica. (2010) Analisis Likuiditas Saham Sebelum dan Sesudah Pengumuman Reverse Stock Split pada Perusahaan yang Terdaftar di Bursa Efek Indonesia. E-journal UAJY. Yogyakarta.

Ikhsan, Arfan. (2009) Akuntansi Manajemen Lingkungan. Yogyakarta: Graha Ilmu

Indonesia Stock Exchange (Bursa Efek Indonesia). Kode Emiten dan Jumlah Saham Beredar. Available at www.idx.co.id. Diakses pada 29 Juli 2015 pukul 16.50.

Kementerian Lingkungan Hidup. (2012) Keputusan Menteri Lingkungan Hidup Republik Indonesia Nomor 273 Tahun 2012 tentang Hasil Penilaian Peringkat Kinerja Perusahaan dalam Pengelolaan Lingkungan Hidup Tahun 2011-2012. Available at proper.menlh.go.id. Diakses pada 25 Juli 2015 pukul 19.25.

Kementerian Lingkungan Hidup. (2013) Keputusan Menteri Lingkungan Hidup Republik Indonesia Nomor 249 Tahun 2013 tentang Hasil Penilaian Peringkat Kinerja Perusahaan dalam Pengelolaan Lingkungan Hidup Tahun 2012-2013. Available at proper.menlh.go.id. Diakses pada 25 Juli 2015 pukul 19.28.

Kementerian Lingkungan Hidup. (2013) Keputusan Menteri Lingkungan Hidup Republik Indonesia Nomor 349 Tahun 2013 tentang Hasil Penilaian Peringkat Kinerja Perusahaan dalam Pengelolaan Lingkungan Hidup Tahun 2012-2013. Available at proper.menlh.go.id. Diakses pada 25 Juli 2015 pukul 19.30 .

Kementerian Lingkungan Hidup. (2013) Keputusan Menteri Lingkungan Hidup Republik Indonesia Nomor 96 Tahun 2013 tentang Perubahan Atas Keputusan Menteri Lingkungan Hidup Nomor 273 Tahun 2012 Tentang Hasil Penilaian Peringkat Kinerja Perusahaan dalam Pengelolaan Lingkungan Hidup Tahun 2011-2012. Available at proper.menlh.go.id. Diakses pada 25 Juli 2015 pukul 19.36.

Kementerian Lingkungan Hidup. (2014) Keputusan Menteri Lingkungan Hidup dan Kehutanan Republik Indonesia Nomor 180 Tahun 2014 tentang Hasil Penilaian Peringkat Kinerja Perusahaan dalam Pengelolaan Lingkungan Hidup Tahun 20132014. Available at proper.menlh.go.id. Diakses pada 25 Juli 2015 pukul 19.40.

Kementerian Lingkungan Hidup. (2014) Keputusan Menteri Lingkungan Hidup Republik Indonesia Nomor 46 Tahun 2014 tentang Perubahan Atas Keputusan Menteri Lingkungan Hidup Nomor 349 Tahun 2013 Tentang Hasil Penilaian Peringkat 
Kinerja Perusahaan dalam Pengelolaan Lingkungan Hidup Tahun 2012-2013. Jakarta. Available at proper.menlh.go.id. Diakses pada 25 Juli 2015 pukul 19.45.

Kementerian Lingkungan Hidup. Program Penilaian Peringkat Kinerja Perusahaan (2013) Deputi Bidang Pengendalian Pencemaran Lingkungan dan Deputi Bidang Pengelolaan B3, Limbah B3 dan Sampah Jakarta.

Linuwih dan Nugrahanti. (2014) "Perbedaan Reaksi Pasar pada Perusahaan Pemenang Indonesia Sustainability Reporting Award (ISRA) (Studi pada Perusahaan Pemenang ISRA periode 2009-2011)". Telaah Bisnis. 15 (1).

Prabandari dan Suryanawa. (2014) Pengaruh Environmental Performance pada Reaksi Investor di Perusahaan High Profile Bursa Efek Indonesia. E-Jurnal Akuntansi Universitas Udayana. 7 (2), (298-312).

Reddy dan Gordon. (2010) The Effect of Sustainability Reporting on Financial Performance: An Empirical Study Using Listed Companies. Asia Entrepreneurship Journal. VI (2).

Sekretariat PROPER Kementerian Lingkungan Hidup. (2010) Laporan Hasil Penilaian Program Peringkat Kinerja Perusahaan dalam Pengelolaan Lingkungan Hidup 2010. Available at proper.menlh.go.id. Diakses pada 25 Juli 2015 pukul 20.01.

Sekretariat PROPER Kementerian Lingkungan Hidup. (2011) Laporan Hasil Penilaian Program Penilaian Peringkat Kinerja Perusahaan dalam Pengelolaan Lingkungan Hidup 2011. Available at proper.menlh.go.id. Diakses pada 25 Juli 2015 pukul 20.07 .

Sekretariat PROPER Kementerian Lingkungan Hidup. (2012) PROPER Periode 20112012 Edisi Pengumuman PROPER November 2012. Available at proper.menlh.go.id. Diakses pada 25 Juli 2015 pukul 20.10.

Siska, Adilla Juita. (2012) "Perbedaan Abnormal Return Perusahaan Sebelum, pada Saat, dan Sesudah Pengumuman Annual Report Award”. Jurnal Ekonomi STIE Haji Agus Salim Bukittinggi. XII (2). Bukit Tinggi.

Tempo Co. (2006) Kasus Buyat. Available at http://www.tempo.co. Diakses pada 7 Februari 2015 pukul 19.42.

Udayanti, Rachmawati Tri. (2012) Analisis Reaksi Pasar Modal Terhadap Pengumuman Peringkat Penilaian Perusahaan dalam Pengelolaan Lingkungan Hidup (PROPER) Oleh KLH RI. Available at http://www.fe.unpad.ac.id. Diakses pada 8 Februari 2015 pukul 15.05.

Widarwati dan Lisviani. (2015) Perbedaan Return Saham pada Perusahaan PROPER, Non PROPER, dan ANTAR PROPER (Studi Kasus pada Sektor Manufaktur dan Semua Sektor PROPER yang tercatat di BEI Tahun 2009-2012). Prosiding Seminar Nasional \& Call for Papers.

Winarto dan Nugrahanti. (2013) Reaksi Pasar di Sekitar Tanggal Pengumuman Opini Audit Wajar Tanpa Pengecualian dengan Paragraf Penjelasan dan Opini Audit Wajar Dengan Pengecualian. Fakultas Ekonomika dan Bisnis Universitas Kristen Satya Wacana Salatiga.

Wiranata dan Wirajaya. (2012) Reaksi Pasar Atas Pengumuman Peringkat Kinerja Perusahaan dalam Pengelolaan Lingkungan. E-Jurnal Akuntansi Universitas Udayana. 8 (3), 408-422.

Yahoo Finance. Harga Saham dan Volume Perdagangan Saham Harian. Available at yahoofinance.com. Diakses pada 28 Juli 2015 pukul 14.05. 